\title{
Microscopic evaluation of clinical measurements of connective tissue attachment levels
}

\author{
Gary C. Armitage ${ }^{1}$, Gunnar K. Svanberg*2 and Harald Lö: ${ }^{3}$ \\ ${ }^{1}$ Division of Periodontology, School of Dentistry, University of California, San Francisco \\ ${ }^{2}$ Department of Oral Biology, University of Michigan, Ann Arbor \\ ${ }^{3}$ School of Dental Medicine, University of Connecticut, Farmington, U.S.A.
}

\begin{abstract}
The purpose of this study was to determine how accurately periodontal probes measure connective tissue attachment levels in beagle dogs with (1) clinically healthy gingivae, (2) experimental gingivitis, and (3) periodontitis. In the healthy and experimental gingivitis specimens the probes were inserted with a standardized force of 25 ponds. In periodontitis specimens the probes were inserted with a gentle, but nonstandardized force. After insertion, 120 plastic periodontal probes ( 40 in each group) were held in place by fusing them to the teeth. Blocks of periodontal tissue with the probes in situ were subsequently processed and serially sectioned. Histometric measurements were made from the sections in order to compare the level of connective tissue attachment to the level of probe penetration. In healthy specimens the probes consistently failed to reach the apical termination of the junctional epithelium $(\overline{\mathrm{x}}=-0.39 \mathrm{~mm})$. In the experimental gingivitis group most probes came closer to the apical termination of the junctional epithelium, but on the average still fell short by $\overline{\mathrm{x}}=-0.10 \mathrm{~mm}$. In periodontitis specimens the probes consistently went past the most apical cells of the junctional epithelium $(\tilde{\mathrm{x}}=+0.24 \mathrm{~mm})$. A significant relationship between the degree of inflammation and level of probe penetration was found. No relationship was observed between histological and clinical sulcus depths. It is concluded that in beagle dogs (1) periodontal probes do not precisely measure connective tissue attachment levels, (2) inflammation has a significant influence on the degree of probe penetration, and (3) histological and clinical sulcus depths differ significantly.
\end{abstract}

Periodontal probes are the most widely used diagnostic instruments for assessing detachment of periodontal tissues from the teeth. The histological endpoint of clinical probing, however, has not been systematically examined. As a result, the question of whether or not clinical probing accurately measures connective tissue attachment levels remains unanswered (Everett 1971).
Based on the belief that no structural connection exists between the gingival epithelium and the tooth, early authors assumed that periodontal probes inserted between the tooth and gingiva met little resistance until the first connective tissue fibers embedded in cementum were reached (Black 1915). In 1921, however, Gottlieb introduced the concept that a firm organic

*Present address: Faculty of Odontology, Fack, S-400 33 Gothenburg 33, Sweden. 
connection existed between epithelial cells and the tooth surface. He believed that this epithelial attachment was strong enough to withstand insertion of periodontal probes under clinical conditions. Gottlieb's concept remained essentially unchallenged until Waerhaug (1952) published a series of experimental studies suggesting that epithelialtooth interfaces were weak and therefore unable to stop thin metal strips from reaching the connective tissue, even under light insertion forces of only 1-4 grams. While it is now known that epithelial cells can form a connection to the tooth surface, the strength of this attachment and its ability to resist insertion of periodontal probes have not been determined (Schroeder \& Listgarten 1971, Listgarten 1972).

Peripheral to the argument of whether or not there is a "firm" epithelial attachment, numerous studies appeared in the literature which microscopically examined the position of foreign bodies inserted between the tooth and gingiva (Waerhaug 1952, 1960, Zander 1956, Orban et al. 1956, Orban 1960, Weinreb 1960, Cohen 1962). Only in Waerhaug's experiments (1952) were insertion forces measured. He used thin metal strips as probes and concluded that in all instances the probe ended at the base of the "pocket epithelium." Orban et al. (1956) and Orban (1960) were unable to reproduce Waerhaug's results and suggested that the thin metal strips severed the epithelial attachment and therefore did not adequately represent clinical probing conditions.

In a study more closely simulating clinical conditions, Lawther (1957) microscopically examined the position of plastic replicas of probes inserted under "normal clinical pressures." He found that connective tissue apical to the junctional epithelium provided the apparent barrier to probe insertion. Sivertson \& Burgett (1976) compared clinical probing measurements to those obtained after tooth extraction. They concluded that thin periodontal probes penetrate to the coronal level of the connective tissue attachment. In a very similar study, Saglie, Johansen \& FIøtra (1975) came to a different conclusion. They found that clinical pocket readings were usually greater than those obtained from measurements on extracted teeth.

Recently, it has been speculated that the extent of probe penetration varies a great deal, depending on such factors as probe thickness, insertion force, degree of inflammatory infiltrate and adjacent connective tissue destruction (Listgarten 1972, Neiders 1972). Available studies on clinical probing have not taken into account all of these variables, particularly insertion force and degree of inflammation. Therefore, this investigation was undertaken to determine how closely the level of periodontal probe penetration corresponds to the level of connective tissue attachment in teeth with (1) clinically healthy gingivae, (2) experimental gingivitis, and (3) advanced periodontitis.

\section{Material and Methods}

Nine inbred beagle dogs, 8 females and 1 male, weighing 9-12 $\mathrm{kg}$ each were selected and placed into three groups on the basis of their periodontal status. The groups each contained three dogs and were termed the clinically healthy group, the experimental gingivitis group, and the periodontitis group.

The periodontitis group consisted of three female dogs which were 5-6 years old and showed clinical signs of advanced periodontal disease such as: gingival recession, pocket formation, spontaneous gingival hemorrhage, purulent exudate, increased tooth mobility and roentgenographic evidence of bone loss.

The remaining six dogs were 10-11 months of age and at the time of selection 
all showed clinical signs of mild gingivitis. During a pre-experimental period of 60 days these dogs were placed on a plaque control regimen intended to bring them to a state of clinical health. The animals initially had their teeth thoroughly scaled and polished with a rubber cup and pumice. For the next 30 days the teeth were cleaned once daily with a soft toothbrush using a modification of the method described by Bass (1948). After this 30-day period the teeth were polished once again with a rubber cup and pumice. During the next 27 days the animals received, in addition to the toothbrushing, one daily topical application of a $0.2 \%$ aqueous solution of chlorhexidine gluconate. During the last 3 days of the plaque control period the animals received topical applications of the chlorhexidine solution only. Clinical health was assessed on the basis of gingival exudate measurements (Löe \& Holm-Pedersen 1965) and the Gingival Index (Löe \& Silness 1963).

Three of the six dogs which had undergone the plaque control program were placed in the clinically healthy group. The group consisted of 2 females and 1 male. The remaining three female dogs were put in the experimental gingivitis group. They were allowed to develop gingivitis by withdrawing all plaque control and by placing them on a soft diet (blended Friskies ${ }^{\circledR}$ and water $)^{1}$. The development of gingivitis was monitored at weekly intervals for 8 weeks. Plaque Index (Silness \& Löe 1964) and Gingival Index (Löe \& Silness 1963) scores were recorded. Gingival exudate measurements were made (Löe \& Holm-Pedersen 1965). The teeth and gingivae were dried using a gentle blast of air for 5-10 seconds. Strips of Whatman No. 1 chromatography paper $^{2}$ cut to $1.5 \times 10 \mathrm{~mm}$ were placed at

\footnotetext{
${ }^{1}$ Carnation Company, Los Angeles, Calif.

${ }^{2}$ W. R. Balston Ltd., London, England
}

the entrance of the gingival crevice and left in situ for $3 \mathrm{~min}$. The strips were then removed, allowed to air dry, and subsequently stained with a $0.2 \%$ alcoholic solution of ninhydrin. The length of the stained area was measured to the nearest $0.2 \mathrm{~mm}$ using an illuminated magnifying glass and calipers.

Periodontal probes. In order to allow sectioning of the periodontal tissues with the probes in position, handmade methyl methacrylate probes were used. Wax impressions of a Michigan No. 1 periodontal probe ${ }^{3}$ with a terminal diameter of $0.35 \mathrm{~mm}$ were taken and then filled with self-curing methyl methacrylate ${ }^{4}$. The resulting plastic probe tips were approximately $10 \mathrm{~mm}$ long with a mean terminal diameter of $0.38 \mathrm{~mm}$ (S.E. $\pm 0.005)$.

Standardization of insertion forces. In order to standardize the insertion forces, a simple, pressure-sensitive periodontal probe holder was designed and constructed (Fig. 1). The device was made from a 16-gauge around needle catheter ${ }^{5}$. The catheter was transparent and allowed direct observation of any movement of a needle shaft located inside the catheter. A small spring made from stainless steel wire with a diameter of 0.1 $\mathrm{mm}$ was placed around the needle shaft. Each plastic probe tip could be attached to the needle shaft by a 3-4 mm segment of polyethylene tubing ${ }^{6}$. When assembled and attached by methyl methacrylate to a standard periodontal probe handle, the device was calibrated using a balance. Calibration marks corresponding to $15,20,25,30$, and 35 ponds $^{7}$ were placed on the catheter por-

${ }^{3}$ Marquis Dental Mfg. Co., Denver, Colorado

${ }^{4}$ Duralay ${ }^{\circledR}$, Reliance Dental Mfg. Co., Worth, Illinois.

${ }^{5}$ Bardic ${ }^{\circledR}$, C. R. Bard, Inc., Murray Hill, N. J.

${ }^{6}$ Intramedic ${ }^{\circledR}$, Clay Adams, Parsippany, N. J.

'1 pond $=0.0098 \mathrm{~N}$. 


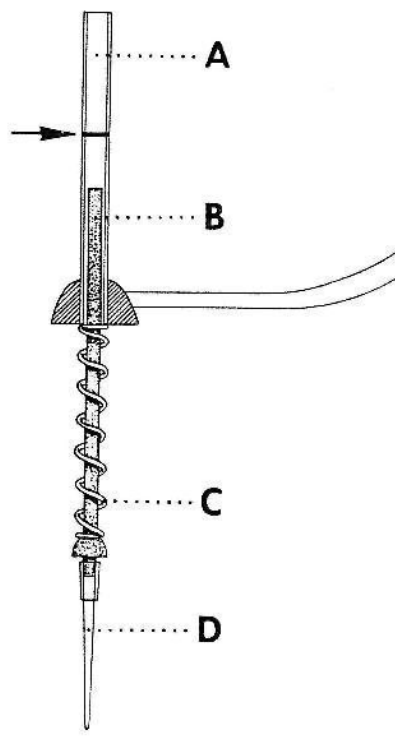

Fig. 1. Diagram of a pressure-sensitive periodontal probe holder. A transparent catheter (A), needle shaft (B), and a delicate spring (C) make up the basic components of the instrument. Any type of periodontal probe tip (D) can be attached to the device. A calibration mark (arrow) corresponding to a force of 25 ponds has been placed on the catheter. The transparent catheter allows direct observation of any movement of the needle shaft.

Skizze des druckempfindlichen Halters für $\mathrm{Pa}$ rodontalsonden. Die Hauptbestandteile dieses Instrumentes sind: (A) Der durchsichtige $\mathrm{Ka}$ theter, $(B)$ der Nadelschaft und $(C)$ die druckempfindliche Feder. Das Instrument kann mit allen Typen parodontaler Sondenspitzen zusammen, angewendet werden. An dem Katheter ist ein Eichstrich angebracht, der einer Kraftmessung von 25 Pond entspricht. Der durchsichtige Katheter ermöglicht die direkte Beobachtung einer jeden Bewegung des Nadelschaftes.

Schéma du support à sonde parodontale, avec dispositif sensible à la pression. Un cathéter transparent $(A)$, une mince tige $(B)$ et un délicat ressort (C) sont les parties essentielles de cet instrument. On peut fixer n'importe quel type de pointe de sonde parodontale (D) sur cet appareil. Un repère (flèche) correspondant à une force de 25 ponds a été placé sur le cathéter. Grâce au cathéter transparent, il est possible d'observer directement tout mouvement de la mince tige. tion of the instrument. The end result was a device that could register a selected insertion force.

In the present investigation this pressuresensitive probe holder was used to insert each probe with a force of 25 ponds. This force was selected because it falls within the middle range of what has been termed "gentle probing" (Gabathuler \& Hassell 1971). In the periodontitis group the pressure-sensitive probe holder was not available for use and therefore these probes were inserted with an unknown, but gentle force.

Probe placement. Each animal was tranquilized with $10 \mathrm{mg}$ of acepromazine maleate ${ }^{8}$ (IM) and then anesthetized with $2 \%$ sodium thiopental ${ }^{9}$ (IV). Small cavity preparations with undercuts were placed in the buccal surfaces of those teeth to receive probes. Care was taken to keep the preparations well away from the gingival margin. Each preparation was subsequently filled with methyl methacrylate so that a knob of the plastic extended approximately $2-3 \mathrm{~mm}$ out from the tooth surface. After all of the plastic fillings were placed, a neck dissection was done to prepare the animal for a carotid perfusion.

Immediately prior to perfusion, the periodontal probes were inserted. The tip of the probe was placed against the tooth surface and then moved below the gingival margin. An attempt was made to insert each probe in line with the long axis of the root and to keep the probe tip in contact with the tooth surface. Once a force of 25 ponds registered on the pressure-sensitive probe holder, the probe was held steady while an assistant fused the probe to the plastic filling using methyl methacrylate. The fusion process

\footnotetext{
${ }^{8}$ Ayerst Laboratories Inc., N. Y.

9 Pentothal ${ }^{\circledR}$, Abbott Laboratories, North Chicago, Illinois.
} 
usually took from 60-90 seconds. Once the probe was firmly attached to the plastic filling, a hot spatula was used to sever the junction between the probe and its holder.

After the last probe was placed, the right and left carotids were cannulated and connected to a perfusion set similar to that described by Egelberg (1966). Each carotid was injected with 1,000 units of sodium heparin ${ }^{11}$ and $40 \mathrm{mg}$ of $2 \%$ lidocaine $\mathrm{HCl}^{12}$. The animal was then killed with an overdose of sodium pentobarbital ${ }^{10}$ and the jugular veins were cut. The head was then flushed with $1.5-2$ liters of $0.9 \%$ saline using gravity as the perfusing force. This was followed by a $10-\mathrm{min}$ period of $0.9 \%$ saline mixed with neutral $10 \%$ phosphate buffered formalin. The last $30 \mathrm{~min}$ of the perfusion consisted of 1.5-2 liters of $10 \%$ phosphate buffered formalin alone. The jaws were removed and placed in $10 \%$ formalin for at least $24 \mathrm{~h}$.

\section{Histologic preparation. After fixation,} blocks of tissue approximately $5 \mathrm{~mm}$ wide and $10 \mathrm{~mm}$ long were removed from each probing site. Each block included at least $2 \mathrm{~mm}$ of gingiva both mesial and distal to the probe, alveolar bone, part of the root, and that portion of the crown with the plastic filling. After decalcification in formic acid-citrate (Luna 1968), the specimens were dehydrated in a sequentially graded series of ethylene glycol, isopropyl alcohol, and epon. This unconventional method of dehydration was necessary to prevent the plastic probes from dissolving. After dehydration, the blocks were embedded in epon and oriented so that they could be sectioned in a bucco-lingual direction. Se-

\footnotetext{
${ }^{10}$ Uthol ${ }^{\circledR}$, W. A. Butler Co., Columbus, Ohio

${ }_{11}$ Panheprin ${ }^{\circledR}$, Abbott Laboratories, North Chicago, Illinois

12 Elkins-Sinn, Inc., Cherry Hill, N. J.
}

rial sections, $5 \mu \mathrm{m}$ thick, were cut with glass knives using the long axis of the probe as a guide for the plane of sectioning.

Analysis of sample. A total of 258 probes were inserted during the study. From each group of dogs, 10 probe specimens were randomly selected for each of the following tooth categories: incisors, canines, premolars, and "molars" (lower first molars and maxillary fourth premolars). Therefore, a total of 120 probes, 40 from each of the three groups, were used for microscopic examination and analysis.

Tracings, at a magnification of $30 \mathrm{X}$, were made of sections from the probing site and approximately $1 \mathrm{~mm}$ mesial and distal to the probing site. The tracings were used for several histometric measurements. The data were evaluated using the Student's ttest, analysis of variance, and correlation coefficients.

"Probing error" as used in this paper refers to the distance from the tip of the probe to the apical termination of the junctional epithelium.

\section{Results}

Periodontal status of groups. At the time of the probing experiment most of the specimens included in the clinically healthy group showed no signs of inflammation as measured by the Gingival Index system (mean $\mathrm{GI}=0.08$ ) or by gingival exudate measurements (mean $\mathrm{GE}=0.02 \mathrm{~mm}$ ) $(\mathrm{Ta}$ ble 1). By these same criteria, all specimens included in the experimental gingivitis group were inflamed (mean GI $=1.65$, mean $\mathrm{GE}=1.53 \mathrm{~mm}$ ) (Table 1). Histologically, none of the specimens in either the healthy or gingivitis groups showed any loss of connective tissue attachment (i.e. the distance from the cemento-enamel junction to the apical termination of the junctional epithelium $=0$ ). 
Table 1. Periodontal disease status of clinically healthy and experimental gingivitis groups as measured by the Gingival Index system and gingival exudate measurements

Das Vorkommen parodontaler Erkrankungssymptome bei klinisch gesunden Versuchsgruppen, sowie bei Gruppen mit experimentell induzierter Gingivitis. Beurteilung mit sowohl dem Gingivalen Index System als auch durch Messungen gingivalen Exsudates

Etat parodontal du groupe à gencive cliniquement saine et du groupe de gingivite expérimentale, mesuré par le système de l'Indice Gingival et par la mesure de l'exsudat gingival

$\begin{array}{cc}\begin{array}{c}\text { Mean gin- } \\ \text { gival exu- } \\ \text { date mea- } \\ \text { surements }\end{array} & \begin{array}{c}\text { Number of spe- } \\ \text { cimens with gin- } \\ \text { gival index }\end{array} \\ \text { scores of: } \\ \text { (mm) } & 0 \quad 1 \quad 2\end{array}$

Clinically

healthy

group

0.02

37

$(n=40)$

\section{Experimental}

gingivitis

group

1.53

$(\mathrm{n}=40)$

Mean gingival exudate measurements (mm) (Messungen des durchschnittlichen gingivalen Exsudates (mm), moyenne des mesures de l'exsudat gingival $(\mathrm{mm})$ )

Number of specimens with Gingival Index scores of: 0, 1, 2 (Anzahl der Präparate mit gingivalem Indexgrad: 0, 1, 2, nombre des spécimens ayant un Indice Gingival de: $0,1,2$ )

Clinically healthy group (Gruppe mit klinisch gesunder Gingiva und Parodont, groupe avec gencive cliniquement saine)

Experimental gingivitis group (Gruppe mit experimenteller Gingivitis, groupe avec gingivite expérimentale).

All specimens included in the periodontitis group showed clinical signs of inflammation such as edema, bleeding, color change and purulent exudate. The average loss of connective tissue attachment as measured microscopically was $1.43 \mathrm{~mm}$ (S.E. \pm 0.23 ).
No gingival bleeding upon probing was observed in the clinically healthy or experimental gingivitis specimens. In both groups blanching of the tissue at the insertion site was observed. Bleeding upon probing was a consistent feature of probe insertion in the periodontitis group.

Probing error in measuring connective tissue attachment level. In the clinically healthy group the probes usually stopped short of the apical termination of the junctional epithelium (ATJE) (Fig. 2). The average error was $0.39 \mathrm{~mm}$ (S.E. \pm 0.08 ). In the experimental gingivitis group most probes came closer to the ATJE, but on the average still fell short by $0.10 \mathrm{~mm}$ (S.E. \pm 0.03 ). In the periodontitis group, where insertion forces were not standardized, the probes usually went past the ATJE with an average error of $0.24 \mathrm{~mm}$ (S.E. \pm 0.06 ). The mean distances between the probe tip and the ATJE (probing error) were significantly different between each of the three groups $(P<0.01)$.

Relation between probing error and measures of inflammation. In Table 2 are given the mean probing errors $(\overline{\mathrm{x}})$ and the mean distances from the apical border of densely infiltrated connective tissue to the apical termination of the junctional (pocket) epithelium $(\bar{y})$ for the gingivitis and periodontitis groups. In the gingivitis group there were significant differences $(P<0.01)$ and only a weak correlation $(\mathrm{r}=0.48)$ between probing error and the level of inflammatory infiltrate. For the periodontitis group there were no significant differences and a strong correlation ( $\mathrm{r}=0.78$ ) between probing error and the level of inflammatory infiltrate.

The relation between probing error and Gingival Index scores and gingival exudate measurements is shown in Figures 3 and 4 respectively. The probing errors were sig- 


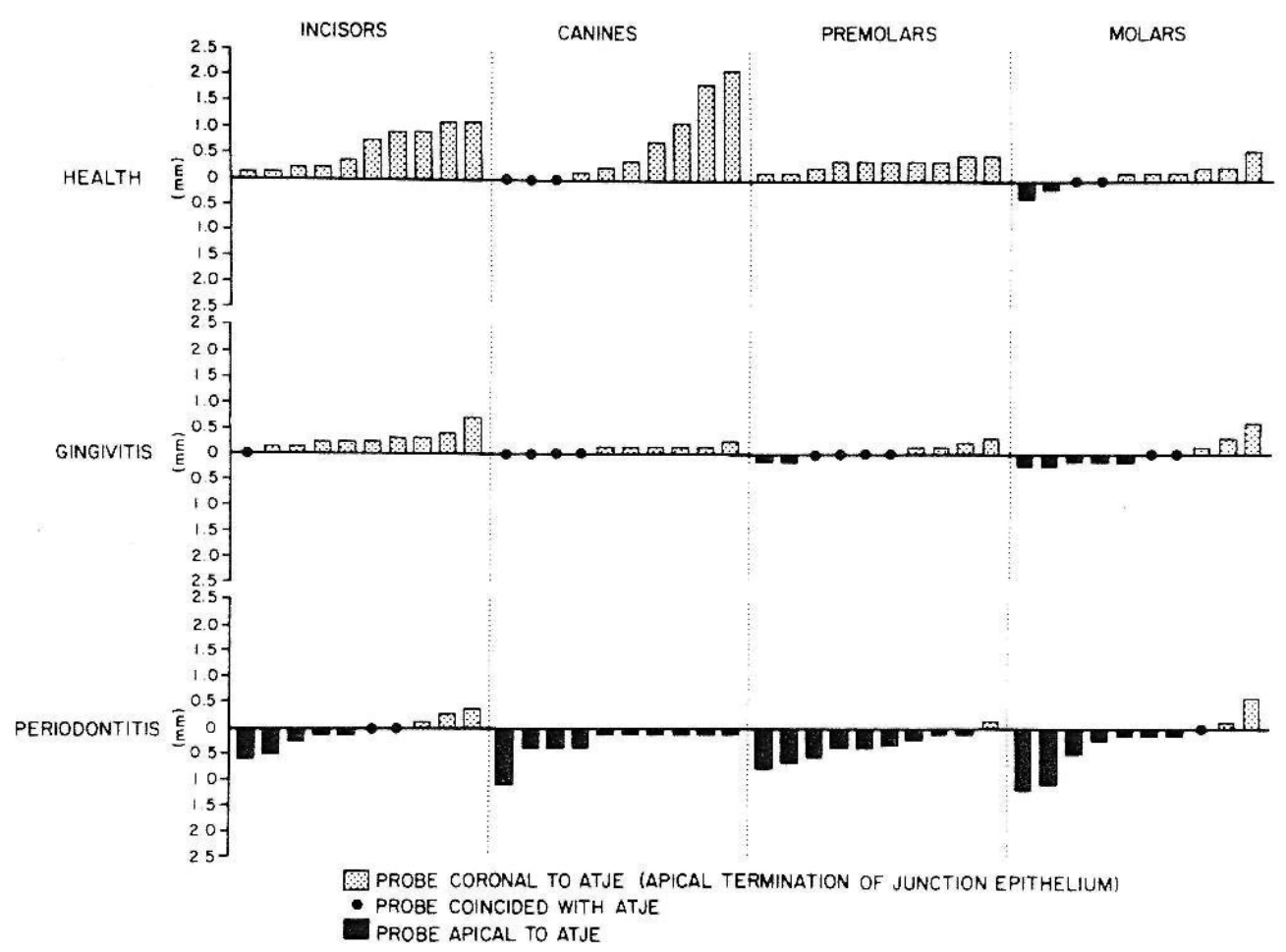

Fig. 2. Magnitude and direction of probing errors in the clinically healthy, experimental gingivitis and periodontitis groups. The probing errors were significantly different between each of the three groups $(P<0.01)$. All 120 probe insertions are shown. Insertion force for the healthy and gingivitis groups was standardized at 25 ponds. The inseration forces for the periodontitis groups were not standardized.

Grösse und Richtung der Sondierungsirrtümer bei klinisch gesunder Gingiva und bei den Versuchsgruppen mit experimentell hervorgerufener Gingivitis und Parodontitis. Der Ausdruck "Sondierungsirrtum" (probing error) bedeutet hier: Abstand von der Sondenspitze zur apikalen Begrenzung des Epithelansatzes (siehe Text). Die bei den drei Gruppen registrierte Anzahl von Sondierungsirrtümern war zwischen den einzelnen Gruppen signifikant unterschiedlich $(P<0.01)$. Sämtliche 120 Sondeninsertionen sind im Diagramm markiert. Bei den gesunden und den Gingivitisgruppen wurde die bei der Sondeninsertion applizierte Kraft mit 25 Ponds standardisiert. Bei der Gruppe mit Parodontitis wurde mit nicht standardisierter Kraft sondiert.

Grandeur et direction des erreurs de sondage dans les groupes de gencive cliniquement saine, de gingivite expérimentale et de parodontites. Les erreurs de sondage (distances entre l'extrémité de la sonde et la limite apicale de l'attache épithiale) présentaient des différences significatives entre les trois groupes $(P<0,01)$. L'insertion des 120 sondes est représentée. Les forces d'insertion étaient standardisées à 25 ponds pour les groupes de gencive saine et de gingivite. Pour le groupe des parodontites, la force n'était pas standardisée.

nificantly greater for samples with a $\mathrm{GI}=$ 0 than for samples with a GI $=1(P<$ $0.05)$ or $\mathrm{GI}=2(P<0.01)$. The probing error for samples with no gingival exudate was significantly greater than for samples with measurable exudate $(P<0.01)$. 
Table 2. Relation between mean probing errors $(\overline{\mathrm{x}})$ and level of inflammatory infiltrate $(\overline{\mathrm{y}}), \mathrm{n}$ $=$ number of observations, S.E. $=$ standard error, $\mathrm{t}=t$ statistic, $\mathrm{F}=\mathrm{F}$ value, $P=$ level of significance, N.S. $=$ no significant difference

$\overline{\mathrm{x}}$ (mean probing error) = mean distance from tip of probe to apical termination of junctional or pocket epithelium. $(-)=$ probe coronal to apical termination of J. E., $(+)=$ probe apical to apical termination of J. E.

$\bar{y}$ (level of inflammatory infiltrate) $=$ mean distance from apical border of densely infiltrated connective tissue to apical termination of junctional or pocket epithelium as measured in sections mesial and distal to probing site. $(-)=$ infiltrate coronal to apical termination of J. E., $(+)=$ infiltrate apical to apical termination of J. E.

Die Beziehung der durchschnittlichen Sondierungsirrtümer $(\bar{x})$ zu dem Niveau des entzündlichen Infiltrates $(\bar{y}) . n=$ Anzahl der Beobachtungen, S.E. $=$ Standard Irrtum, $t=\mathrm{t}-$ Test, $F=$ F-Wert. $\mathrm{P}=$ Signifikanzniveau, N.S. $=$ kein signifikanter Unterschied

$\tilde{x}$ (durchschnittlicher Sondierungsirrtum $)=$ durchschnittlicher Abstand von der Sondenspitze zur apikalen Grenze des Epithelansatzes oder des Taschenepithels. $(-)=$ Die Sonde befindet sich koronal der apikalen Begrenzung des Epithelansatzes., $(+)=$ Die Sonde befindet sich api$k a l$ der unteren Begrenzung des Epithelansatzes.

$\bar{y}$ (Niveau des entzündlichen Infiltrates) $=$ durchschnittlicher Abstand von der apikalen Grenze des dicht infiltrierten Bindegewebes zur apikalen Begrenzung des Epithelansatzes oder des Taschenepithels. Die Messungen erfolgten in Gewebsabschnitten mesial und distal der Sondierungsstelle. $(-)=$ Das Infiltrat befindet sich koronal der apikalen Begrenzung des Epithelansatzes., $(+)=$ Das Infiltrat befindet sich apikal der unteren Begrenzung des Epithelansatzes.

Rapport entre la moyenne des erreurs de sondage $(\bar{x})$ et le niveau de l'infiltration inflammatoire $(\bar{y}) . n=$ nombre d'observations, S.E. $=$ erreur standard, $t=\mathrm{t}$ statistique, $F=$ valeur de $F, P=$ niveau de signification, $N S=$ pas de différence significative.

$\bar{x}$ (moyenne de l'erreur de sondage $)=$ distance moyenne entre l'extrémité de la sonde et la limite apicale de l'attache epithéliale. $(-)=$ sonde du côté coronaire par rapport à la limite apicale de l'attache épithéliale, $(+)=$ sonde du côté apical de la limite apicale de l'attache épithéliale.

$\bar{y}$ (niveau de l'infiltration inflammatoire) $=$ distance moyenne entre la limite apicale du tissu conjonctif massivement infiltré et la limite apicale de l'attache épithéliale, mesurée sur des coupes mésiales et distales par rapport au point de sondage. $(-)=$ infiltration du côté coronaire par rapport à la limite apicale de l'attache épithéliale, $(+)=$ infiltration du côté apical par rapport à la limite apicale de l'attache épithéliale

\begin{tabular}{|c|c|c|c|c|c|c|c|c|}
\hline & $\begin{array}{l}\text { Tooth } \\
\text { group }\end{array}$ & $\mathrm{n}$ & $\overline{\mathrm{x}} \pm$ S.E. & $\bar{y} \pm$ S.E. & $\mathrm{t}$ & $P$ & $\mathrm{~F}$ & $P$ \\
\hline \multirow{5}{*}{$\begin{array}{l}\text { Experimental } \\
\text { gingivitis } \\
\text { (insertion } \\
\text { force of } \\
25 \text { ponds) }\end{array}$} & Incisors & 10 & $-0.24 \pm 0.07$ & $-0.28 \pm 0.10$ & 0.65 & N.S. & 0.10 & N.S. \\
\hline & Canines & 10 & $-0.05 \pm 0.02$ & $-0.44 \pm 0.15$ & 2.63 & $<0.05$ & 6.34 & $<0.05$ \\
\hline & Premolars & 10 & $-0.05 \pm 0.04$ & $-0.12 \pm 0.07$ & 0.96 & N.S. & 0.69 & N.S. \\
\hline & "Molars" & 10 & $-0.04 \pm 0.08$ & $-0.13 \pm 0.08$ & 2.78 & $<0.05$ & 0.65 & N.S. \\
\hline & All teeth & 40 & $-0.10 \pm 0.03$ & $-0.24 \pm 0.04$ & 3.05 & $<0.01$ & 5.45 & $<0.01$ \\
\hline \multirow{5}{*}{$\begin{array}{l}\text { Periodontitis } \\
\text { (insertion } \\
\text { force not } \\
\text { standardized) }\end{array}$} & Incisors & 10 & $+0.07 \pm 0.10$ & $+0.06 \pm 0.07$ & 0.23 & N.S. & 0.01 & N.S. \\
\hline & Canines & 10 & $+0.28 \pm 0.10$ & $+0.19 \pm 0.16$ & 0.93 & N.S. & 0.23 & N.S. \\
\hline & Premolars & 10 & $+0.35 \pm 0.09$ & $+0.32 \pm 0.09$ & 0.65 & N.S. & 0.05 & N.S. \\
\hline & "Molars" & 10 & $+0.25 \pm 0.17$ & $+0.18 \pm 0.15$ & 0.62 & N.S. & 0.11 & N.S. \\
\hline & All teeth & 40 & $+0.24 \pm 0.06$ & $+0.19 \pm 0.06$ & 1.26 & N.S. & 0.35 & N.S. \\
\hline
\end{tabular}

Experimental gingivitis (insertion force of 25 ponds) (Experimentelle Gingivitis (Einführung der Sonde mit einer Kraft von 25 Pond), gingivite expérimentale (force d'insertion de 25 ponds))

Periodontitis (insertion force not standardized) (Parodontitis (Einführungskraft nicht standardisiert), parodontite (force d'insertion non standardisée)). 


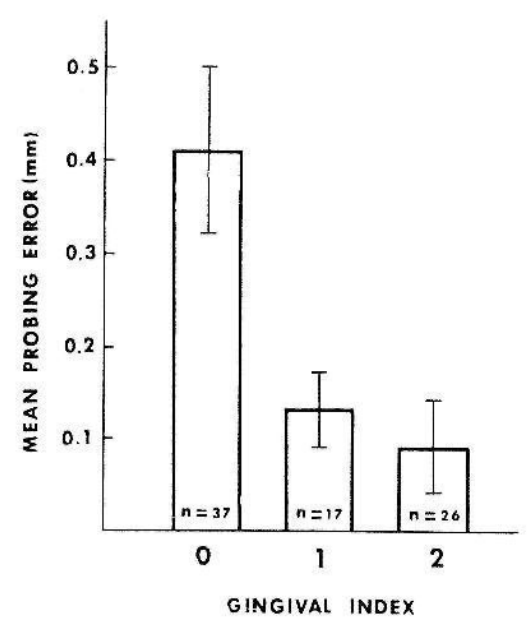

Fig. 3. Relation between probing errors and Gingival Index scores for healthy and experimental gingivitis groups combined. Probing errors for samples representing $\mathrm{GI}=0$ were significantly greater than for samples representing $\mathrm{GI}=1(P<0.05)$ or $\mathrm{GI}=2(P<0.01)$. Probing errors for samples representing $\mathrm{GI}=1$ were not significantly different from those representing $\mathrm{GI}=2$.

Die Beziehung zwischen Sondierungsirrtïmern und Gingivalindex-Werten bei sowohl gesunden als auch bei Gruppen mit experimentell induzierter Gingivitis. Sondierungsirrtümer $\mathrm{ka}$ men bei Untergruppen mit einem $G I=0$ signifikant öfter vor als bei Untergruppen mit $G I=I \quad(P<0,05)$ oder $G I=2 \quad(P<0.01)$. Sondierungsirrtümer bei Untergruppen mit GI $=1$ unterschieden sich nicht signifikant von den Irrtümern bei Untergruppen mit $G I=2$.

Rapport entre les erreurs de sondage et les valeurs de l'Indice Gingival pour les groupes de gencives saines et de gingivite expérimentale considérés ensemble. Les erreurs de sondage des specimens représentant $G I=0$ étaient significativement plus grandes que pour les spécimens représentant $G I=1(P<0,05)$ ou $G I=$ $2(P<0,01)$. Les erreurs de sondage des spécimens représentant $G I=1$ n'étaient pas significativement différentes de celles des spécimens représentant $G I=2$.

Relation between the level of the histological sulcus and probing error. In Table 3 are given the mean probing errors $(\bar{x})$ and

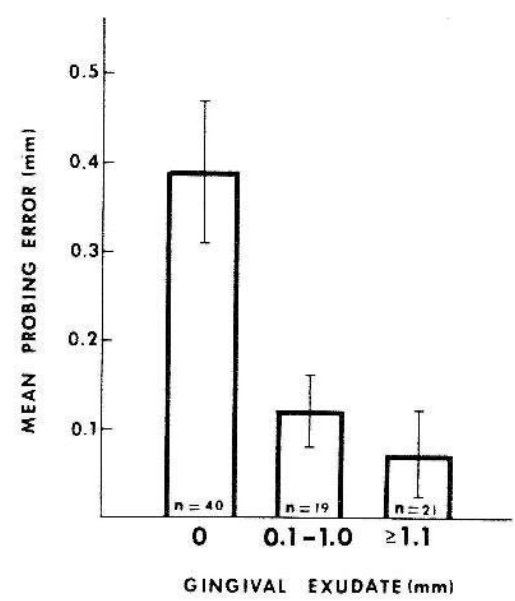

Fig. 4. Relation between probing errors and gingival exudate measurements for healthy and experimental gingivitis groups combined. Probing errors for samples with no gingival exudate were significantly greater than for samples with exudate measurements of $0.1-1.0$ $\mathrm{mm}(P<0.05)$ or $\geq 1.1 \mathrm{~mm}(P<0.01)$. The probing errors between groups of specimens with exudate were not significantly different.

Die Beziehung zwischen Sondierungsirrtümern und der Menge gingivalen Exsudates bei sowohl gesunden als auch bei Gruppen mit experimentell induzierter Gingivitis. Sondierungsirrtümer kamen bei Untergruppen ohne gingivales Exsudat signifikant häufiger vor als bei Untergruppen, bei denen Exsudatmengen von $0.1-$ $1.0 \mathrm{~mm}(P<0.05)$ oder $\geq 1.1 \mathrm{~mm}(P<0.01)$ vorlagen. Zwischen Gruppen mit gingivalem Exsudat lagen keine signifikant unterschiedlichen Sondierungsirrtümer vor.

Rapport entre les erreurs de sondage et les mesures de l'exsudat gingival pour les groupes de gencives saines et de gingivite expérimentale considérés ensemble. Les erreurs de sondage des spécimens ne présentant pas d'exsudat gingival étaient significativement plus grandes que celles des spécimens avec un exsudat dont la mesure était de 0,1-1,0 mm $(P<0,05)$ ou de $\geqslant 1,1 \mathrm{~mm}(P<0,01)$. Les erreurs de sondage entre les groupes de spécimens avec exsudat n'étaient pas significativement différentes.

the mean distances from the bottom of the histological sulcus to the apical termination of the junctional epithelium ( $\bar{z})$ for the clin- 
Table 3. Relation between mean probing error $(\overline{\mathrm{x}})$ and level of histologic sulcus $(\overline{\mathrm{z}}) . \mathrm{n}=$ number of observations, S.E. $=$ standard error, $\mathrm{t}=t$ statistic, $\mathrm{F}=\mathrm{F}$ value, $P=$ level of significance, N.S. = no significant difference.

$\overline{\mathrm{x}}$ (mean probing error) $=$ mean distance from tip of probe to apical termination of junctional epithelium. $(-)=$ probe coronal to apical termination of J.E., $(+)=$ probe apical to apical termination of J.E.

$\overline{\mathrm{z}}$ (level of histologic sulcus) = mean distance from the bottom of the histologic sulcus to the apical termination of the junctional epithelium as measured in sections mesial and distal to probing site. $(-)=$ sulcus bottom coronal to apical termination of the junctional epithelium.

Die Beziehung des durchschnittlichen Sondierungsirrtumes $(\bar{x})$ zu dem Niveau des histologisch ermittelten Sulkus (z). $n=$ Anzahl der Beobachtungen. S.E. Standard Irrtum, $t=\mathrm{t}-$ Test, $F$ $=F-$ Wert $. \mathbf{P}=$ Signifikanzniveau, N.S. $=$ Kein signifikanter Unterschied

$\bar{x}=($ durchschnittlicher Sondierungsirrtum $)=$ durchschnittlicher Abstand von der Sondenspitze zur apikalen Grenze des Epithelansatzes. $(-)=$ die Sonde befindet sich koronal der apikalen Begrenzung des Epithelansatzes., $(+)=$ die Sonde befindet sich apikal der unteren Begrenzung des Epithelansatzes

$\bar{z}$ (histologisch ermitteltes Sulkusniveau $)=$ durchschnittlicher Abstand vom histologisch ermittelten Sulkusboden zur apikalen Grenze des Epithelansatzes. Die Messungen erfolgten in Abschnitten mesial und distal der Sondierungsstelle. $(-)=$ der Sulkusboden befindet sich koronal der apikalen Begrenzung des Epithelansatzes

Rapport entre l'erreur de sondage moyenne $(\bar{x})$ et le niveau du cul-de-sac histologique $(\bar{z})$.

( $\bar{z})$ (niveau du cul-de-sac histologique $)=$ distance moyenne entre le fond du cul-de-sac histologique et la limite apicale de l'attache épithéliale mesurée sur des coupes mésiales et distales par rapport au point de sondage. $(-)=$ fond $d u$ cul-de-sac situé du côté coronaire par rapport à la limite apicale de l'attache épithéliale

\begin{tabular}{|c|c|c|c|c|c|c|c|c|}
\hline & $\begin{array}{l}\text { Tooth } \\
\text { group }\end{array}$ & $\mathrm{n}$ & $\overline{\mathrm{x}} \pm$ S.E. & $\bar{z} \pm$ S.E. & $\mathrm{t}$ & $P$ & $\mathrm{~F}$ & $P$ \\
\hline \multirow{5}{*}{$\begin{array}{l}\text { Clinical } \\
\text { Health } \\
\text { (insertion } \\
\text { force of } \\
25 \text { ponds) }\end{array}$} & Incisors & 10 & $-0.57 \pm 0.14$ & $-0.91 \pm 0.10$ & 2.03 & $<0.05$ & 3.75 & N.S. \\
\hline & Canines & 10 & $-0.66 \pm 0.26$ & $-1.63 \pm 0.20$ & 4.70 & $<0.01$ & 8.98 & $<0.01$ \\
\hline & Premolars & 10 & $-0.28 \pm 0.04$ & $-0.65 \pm 0.07$ & 4.28 & $<0.01$ & 22.62 & $<0.01$ \\
\hline & "Molars" & 10 & $-0.07 \pm 0.06$ & $-0.43 \pm 0.04$ & 12.17 & $<0.01$ & 24.10 & $<0.01$ \\
\hline & All teeth & 40 & $-0.39 \pm 0.08$ & $-0.90 \pm 0.09$ & 6.42 & $<0.01$ & 17.32 & $<0.01$ \\
\hline \multirow{5}{*}{$\begin{array}{l}\text { Experimental } \\
\text { Gingivitis } \\
\text { (insertion } \\
\text { force of } \\
25 \text { ponds) }\end{array}$} & Incisors & 10 & $-0.24 \pm 0.07$ & $-0.88 \pm 0.10$ & 6.55 & $<0.01$ & 26.36 & $<0.01$ \\
\hline & Canines & 10 & $-0.05 \pm 0.02$ & $-1.41 \pm 0.13$ & 10.00 & $<0.01$ & 112.63 & $<0.01$ \\
\hline & Premolars & 10 & $-0.05 \pm 0.04$ & $-0.58 \pm 0.08$ & 4.97 & $<0.01$ & 30.90 & $<0.01$ \\
\hline & "Molars" & 10 & $-0.04 \pm 0.08$ & $-0.71 \pm 0.15$ & 8.64 & $<0.01$ & 15.80 & $<0.01$ \\
\hline & All teeth & 40 & $-0.10 \pm 0.03$ & $-0.89 \pm 0.08$ & 10.92 & $<0.01$ & 94.64 & $<0.01$ \\
\hline
\end{tabular}

ically healthy and gingivitis groups. In the clinically healthy group there were significant differences $(P<0.01)$, but a moderate correlation ( $\mathrm{r}=0.58$ ), between the level of the histological sulcus ( $\bar{z})$ and probing error $(\bar{x})$. For the gingivitis group there were significant differences $(P<0.01)$ and a weak correlation $(r=0.30)$ between $\bar{z}$ and $\bar{x}$.
Histologic observations. A few inflammatory cells and a slight proliferation of sulcular epithelium were routinely observed in histologic sections of the clinically healthy specimens (Fig. 5A). In this group, the inflammation was usually limited to a small area near the gingival margin. There were no histological indications that the probes passed through the sulcular and/or junction- 

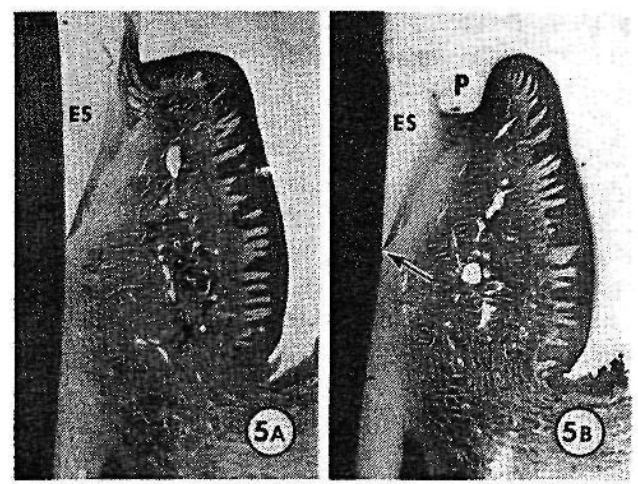

Fig. 5. Buccal gingiva of a lower incisor from the clinically healthy group. $(\mathrm{A})=$ site without probe. $(\mathrm{B})=$ site with probe. The end of the transparent plastic probe $(\mathrm{P})$ is located approximately $0.9 \mathrm{~mm}$ coronal to the apical termination of the junctional epithelium (arrow). $(\mathrm{ES})=$ enamel space. Magn. $30 \mathrm{X}(\mathrm{A}, \mathrm{B})$.

Labiale Gingiva eines unteren Schneidezahnes aus der klinisch gesunden Gruppe. $(A)=$ Situation ohne Sonde. $(B)=$ Situation mit Sonde. Die Spitze der durchsichtigen Kunststoffsonde (P) befindet sich etwa $0.9 \mathrm{~mm}$ koronal des apikalen Epithelansatzes. (Pfeil). ES $=$ Schmelz. 30-fache Vergrösserung $(A, B)$.

Gencive vestibulaire d'une incisive inférieure $d u$ groupe à gencives cliniquement saines. $(A)$ $=$ région sans sonde. $(B)=$ région avec sonde. L'extrémité de la sonde de matière plastique transparente $(P)$ est située du côté coronaire à environ $0,9 \mathrm{~mm}$ de la limite apicale de l'attache épithéliale (flèche). (ES) = espace de l'émail. Grossissement $30 X .(A, B)$.

al epithelium to come in direct contact with connective tissue (Fig. 5B). In all of the clinically healthy specimens there appeared to be a layer of compressed epithelial cells between the probe and connective tissue.

In the experimental gingivitis group, inflammatory cells and epithelial proliferation were usually observed along the entire distance from gingival crest to the apical termination of the junctional epithelium (Fig. $6 \mathrm{~A})$. No direct contact between probe and connective tissue was microscopically observed (Fig. 6B).

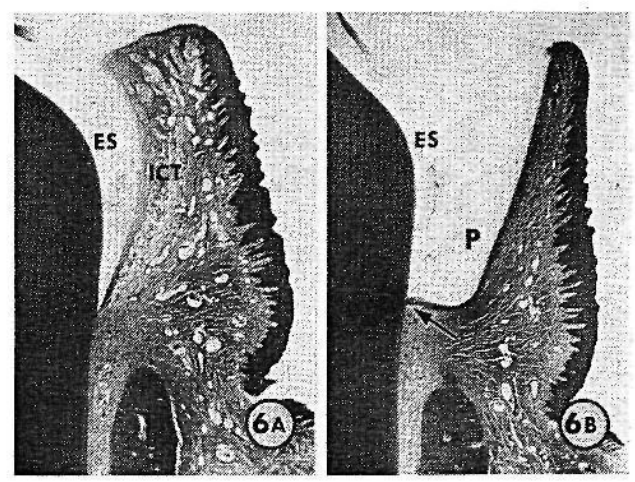

Fig. 6. Buccal gingiva from a lower 2 nd premolar with experimental gingivitis. $(A)=$ site without probe. Note inflamed connective tissue (ICT) adjacent to the dentogingival interface. (B) $=$ site with probe. Transparent plastic probe $(\mathrm{P})$ has penetrated to the apical termination of the junctional epithelium (arrow). $(\mathrm{ES}=$ enamel space. Magn. $28 \times$ X (A, B).

Bukkale Gingiva eines zweiten Prämolaren mit experimentell induzierter Gingivitis. (A) Situation ohne Sonde. Beachten Sie das entzündete Bindegewebe (ICT) in direktem Anschluss an die Grenzfläche zwischen Zahn und Gingiva. (B) Situation mit Sonde. Die durchsichtige Kunststoffsonde (P) hat die Tasche bis zur apikalen Grenze des Epithelansatzes (Pfeil) hin penetriert. $E S=S c h m e l z .28$-fache Vergrösserung $(A, B)$.

Gencive vestibulaire d'une deuxième prémolaire inférieure avec gingivite expérimentale. $(A)=$ région sans sonde. Remarquer l'inflammation du tissu conjonctif (ICT) adjacent à la limite dento-gingivale. $(B)=$ région avec sonde. La sonde de plastique transparent a pénétré jusqu'à la limite apicale de l'attache épithéliale (flèche). $(E S)=$ espace de l'émail. Grossissement $28 X(A, B)$.

The histologic picture of periodontitis specimens was characterized by a heavy inflammatory infiltrate, extensive connective tissue destruction and marked epithelial proliferation (Figs. 7-8). In several specimens the probes had passed through the epithelium and were in direct contact with connective tissue (Figs. 7-8). In other specimens, however, no probe-connective tissue 

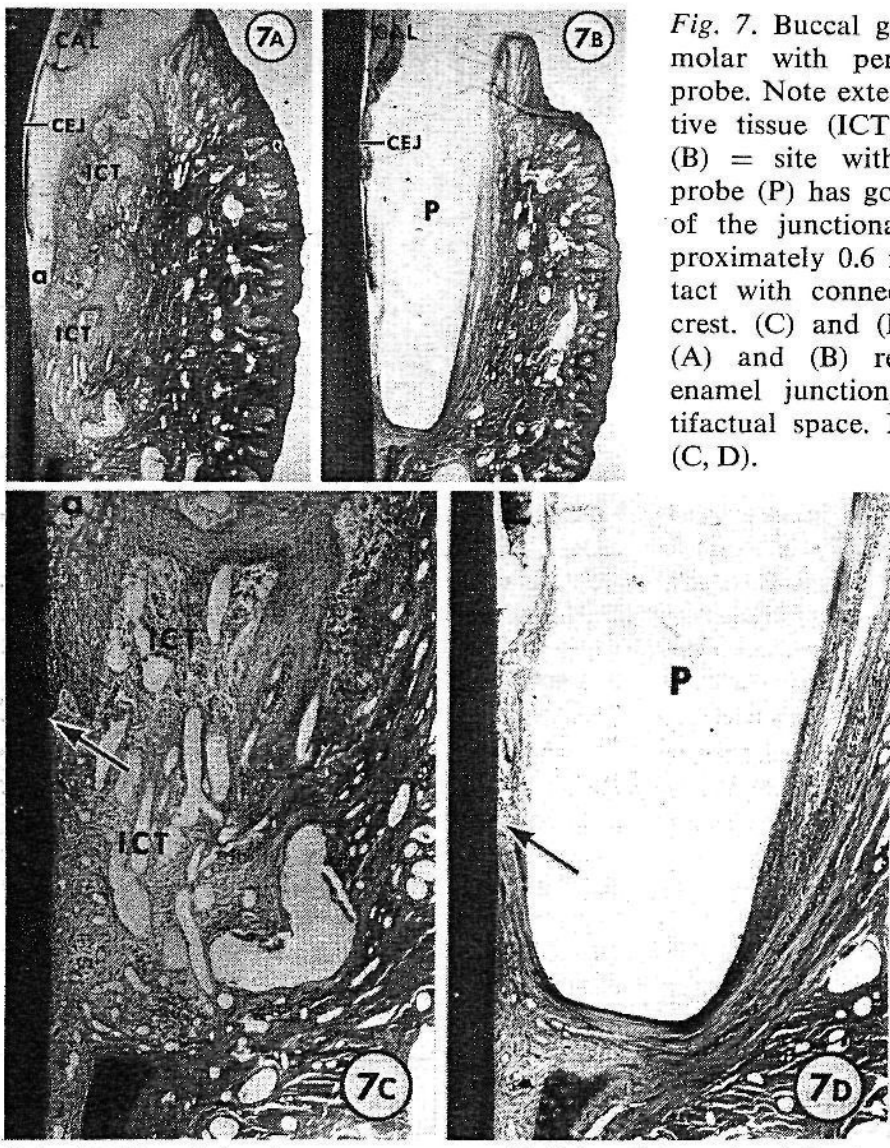

Bukkale Gingiva bei einem zweiten Prämolaren mit Parodontitis. (A) Situation ohne Sonde. Beachten Sie die ausgedehnte Fläche entzïindeten Bindegewebes (ICT) und die epitheliale Proliferation. (B) Situation mit Sonde. Die durchsichtige Kunststoffsonde (P) hat die Tasche um etwa $0.6 \mathrm{~mm}$ über die apikale Begrenzung des Epithelansatzes hinaus (Pfeil) penetriert. Die Sondenspitze befindet sich in Kontakt mit dem Bindegewebe nahe der knöchernen Alveole. (C) und $(D)=$ höhere Vergrösserung von (A) bzw. (B). $(C E J)=$ Schmelzzementgrenze, $(C A L)=$ Zahnstein, (a) Artefakt. 29-fache Vergrösserung $(A, B)$ und 75 -fache $(C, D)$.

Gencive vestibulaire d'une deuxième prémolaire inférieure avec parodontite. $(A)=$ région sans sonde. Remarquer la zone étendue d'inflammation du tissu conjonctif (ICT) et la prolifération épithéliale. $(B)=$ région avec sonde. La sonde de plastique transparent $(P)$ a dépassé la limite apicale de l'attache épithéliale (flèche) d'environ 0,6 $\mathrm{mm}$. L'extrémité de la sonde est en contact avec le tissu conjonctif près de la crête alvéolaire. $(C)$ et $(D)=$ plus fort grossissement de $(A) \cdot e t$ de $(B) .(C E J)=$ jonction émail-cément, $(C A L)=$ tartre, $(a)=$ espace dû̀ à un artéfact. Grossissement $29 X(A, B)$ et $75 X(C, D)$.

contact was observed (Figs. 9-10). Probe contact with alveolar bone did not occur. The distance from maximum probe penetration to alveolar bone was highly variable (range $=0.1-2.45 \mathrm{~mm}$; mean \pm S.E. $=$ $0.93 \pm 0.10 \mathrm{~mm})$. On the few occasions when the probe came within $0.1 \mathrm{~mm}$ of the alveolar crest a compressed layer of con- nective tissue was always observed between the probe and the bone (Figs. $7 \& 9$ ).

Even though during insertion an attempt was made to keep the probe tip in contact with the tooth surface, occasionally the probe ended up as far as $0.4 \mathrm{~mm}$ away from the tooth (Fig. 8). When this happened the probe had usually passed through 
Fig. 8. Buccal gingiva from a lower 4th premolar with periodontitis. $(A)=$ site without probe. $(B)=$ site with probe. Transparent plastic probe $(\mathrm{P})$ is approximately $0.4 \mathrm{~mm}$ away from the tooth surface. The probe has passed through an area of inflamed connective tissue (ICT). (C) and (D) = higher magnifications of (A) and (B) respectively. Probe tip is apical to the apical termination of the junctional epithelium (arrow) and is in direct contact with connective tissue fibers .Magn. $28 \times(\mathrm{A}, \mathrm{B})$ and $54 \mathrm{X}(\mathrm{C}, \mathrm{D})$.

Bukkale Gingiva eines vierten Prämolaren mit Parodontitis. (A) Situation ohne Sonde. (B) Situation mit Sonde. Die durchsichtige Kunststoffsonde $(P)$ befindet sich etwa $0.4 \mathrm{~mm}$ von der Zahnoberfläche entfernt. Die Sonde hat einen entzündeten Bindegewebsabschnitt penetriert (ICT). (C) und (D) = hö-
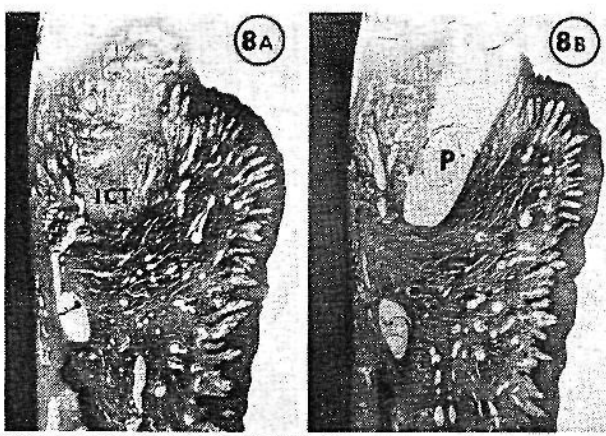

here Vergrösserung von $(A)$ bzw. (B). Die Sondenspitze befindet sich unterhalb der apikalen Begrenzung des Epithelansatzes (Pfeil) in Kontakt mit Bindegewebsfasern. 28-fache Vergrösserung $(A, B)$ und 54-fache $(C, D)$.

Gencive vestibulaire d'une quatrième prémolaire inférieure avec parodontite. $(A)=$ région sans sonde. $(B)=$ région avec sonde. La sonde de plastique transparent $(P)$ reste à environ $0,4 \mathrm{~mm}$ de la surface dentaire. La sonde a traversé une zone d'inflammation du tissu conjonctif (ICT). (C) et $(D)=$ plus fort grossissement de $(A)$ et de $(B)$. L'extrémité de la sonde est placée à un niveau plus apical que la limite apicale de l'attache épithéliale (flèche) et est en contact direct avec les fibres de tissu conjonctif. Grossissement $28 X(A, B)$ et $54 X(C, D)$.

an area of extensive connective tissue destruction and inflammation.

\section{Discussion}

The present investigation has shown that periodontal probes used in beagle dogs with clinically healthy gingivae stopped short of the apical termination of the junctional epithelium by an average of $0.39 \mathrm{~mm}$. The probing error was significantly greater in incisors and canines than in posterior teeth (Fig. 2). In dogs with experimental gingivitis the probes came closer to the apical termination of the junctional epithelium, but on the average still fell short by $0.10 \mathrm{~mm}$.
A different situation was observed in dogs with periodontitis where the probes went past the apical termination of the junctional epithelium by an average of 0.24 $\mathrm{mm}$. Since the insertion force used for the periodontitis specimens was not standardized, the results from this group connot be validly compared to those from the healthy and gingivitis groups. An attempt was made, however, to insert the probes in the periodontitis specimens in a manner consistent with routine clinical practices. That is, the probes were inserted with a very light force until definite, yet resilient, resistance was felt. Gabathuler \& Hassell (1971) have reported that "gentle probing" 


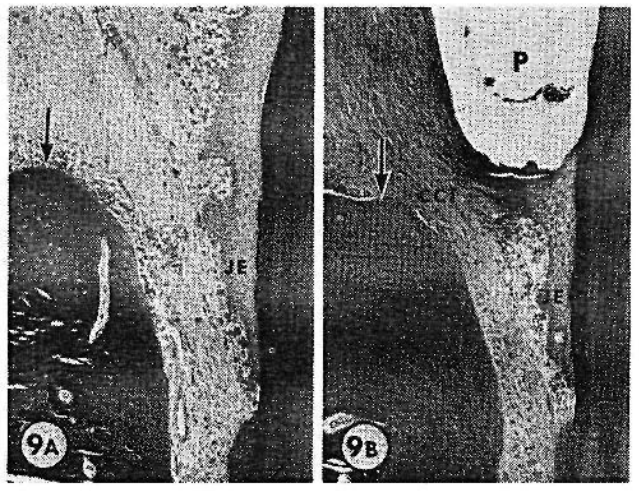

Fig. 9. Buccal gingiva from a lower 1st molar with periodontitis. $(\mathrm{A})=$ site without probe. Note that the junctional epithelium (JE) is approximately $0.5 \mathrm{~mm}$ apical to the alveolar crest (arrow). $(\mathrm{B})=$ site with probe. Transparent plastic probe $(\mathrm{P})$ is approximately 0.1 $\mathrm{mm}$ from the alveolar crest. Note the compressed layer of connective tissue (CCT) between probe and bone. Magn. 81 X (A, B).

Bukkale Gingiva eines unteren ersten Molaren mit Parodontitis. $(A)=$ Situation ohne Sonde. Beachten Sie, dass sich der Epithelansatz etwa $0.5 \mathrm{~mm}$ apical von der knöchernen Alveole befindet $($ Pfeil) $) .(B)=$ Situation mit Sonde. Die durchsichtige Kunststoffsonde (P) befindet sich etwa $0.1 \mathrm{~mm}$ von der knöchernen Alveole entfernt. Beachten Sie die komprimierte Schicht Bindegewebe (CCT) zwischen Sonde und Knochen. 81-fache Vergrösserung $(A, B)$.

Gencive vestibulaire d'une première molaire inférieure avec parodontite. $(A)=$ région sans sonde. Remarquer que l'attache épithéliale est à $0,5 \mathrm{~mm}$ de la crête alvéolaire (flèche), en direction apicale. $(B)=$ région avec sonde. $L a$ sonde de plastique transparent $(P)$ est à environ $0,1 \mathrm{~mm}$ au dessus de la crête alvéolaire. Remarquer la couche comprimée de tissu conjonctif (CCT) entre la sonde et l'os. Grossissement $81 X(A, B)$.

such as this involves forces of 20.2-32.6 ponds.

Findings from the present study suggest that inflamed tissues offer less resistance to probe penetration than clinically healthy tissues. This suggestion is supported by observations from the healthy and gingivitis groups. Sig-
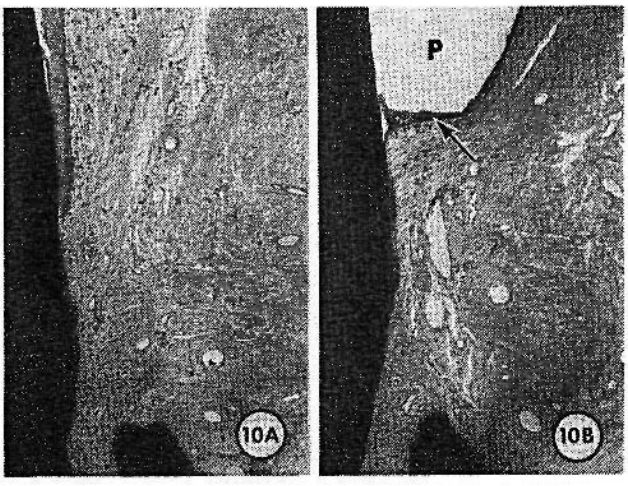

Fig. 10. Buccal gingiva from an upper 4th premolar with periodontitis $(A)=$ site without probe. (B) = site with probe. Between the transparent plastic probe $(\mathrm{P})$ and connective tissue is a compressed layer of epithelial cells (arrow). Magn. 70 X (A, B).

Bukkale Gingiva eines oberen vierten Prämolaren mit Parodontitis. (A) Situation ohne Sonde. $(B)=$ Situation mit Sonde. Zwischen der durchsichtigen Kunststoffsonde $(P)$ und dem Bindegewebe befindet sich eine komprimierte Schicht epithelialer Zellen (Pfeil). 70fache Vergrösserung $(A, B)$.

Gencive vestibulaire d'une quatrième prémolaire supérieure avec parodontite. $(A)=$ région sans sonde. Un espace dû̀ à un artéfact (a) est visible à la limite entre la surface de l'épithélium et la surface de la dent. $(B)=$ région avec sonde. Entre la sonde de plastique transparent $(P)$ et le tissu conjonctif, il y a une couche comprimée de cellules épithéliales (flèche). $(J E)=$ attache épithéliale. Grossissement $70 X(A, B)$.

nificantly greater probing errors were observed in noninflamed (i.e. $\mathrm{GI}=\mathrm{O}$, no gingival exudate) specimens from these groups than in inflamed (i.e. GI $\geq 1$, gingival exudate $\geq 0.1 \mathrm{~mm}$ ) specimens (Figs. 3 \& 4). Results from the periodontitis group, while not comparable to the above findings, also indicate that inflammation influences probe penetration. In this group there were no significant differences between the apical level of the inflammatory infiltrate and probe penetration (Table 2). In other words, 
the probes stopped when they reached intact and noninflamed connective tissue. This agrees with the earlier report of Lawther (1957) from observations in human specimens.

Under the conditions of this study, the depth of the histological sulcus had no observable effect on the level of probe penetration. In both the clinically healthy and gingivitis groups, there were significant differences between the level of the histological sulcus and the level of probe penetration (Table 3). This finding confirms the suggestion that histological and clinical sulcus depths may be quite different (Schroeder \& Listgarten 1971).

The results of this investigation appear to contradict those of Sivertson \& Burgett (1976) who examined teeth with periodontitis and concluded, "In routine clinical probing, a thin periodontal probe will penetrate to the coronal level of the connective tissue attachment which must be assumed to represent the base of the epithelial attachment." This is true in only 3 of the 40 periodontitis specimens from the present study (Fig. 2). Differences in methodology between the studies may partially account for the contrasting results. Our findings, however, tend to agree more closely with those of Saglie et al. (1975) and Listgarten et al. (1976).

Under clinical conditions it is expected that probe measurements are subject to several built-in problems such as the inability to: (1) standardize insertion forces, (2) accurately read probe graduations, and (3) predict the extent of probe penetration in health and disease. Because of these problems, probing variations of up to 1 millimeter are anticipated and usually accepted (Glavind \& Löe 1967). Although most clinicians are cognizant of these inherent problems, the assumption is still generally made that probe measurements represent a useful approximation of connective tissue at- tachment levels. The comparatively small "probing errors" encountered in the present study indicate that such an assumption is reasonable from a clinical point of view. In other words, in the clinic where slight errors are acceptable, properly used thin periodontal probes are satisfactory.

Caution should be exercised, however, when interpreting the results of longitudinal investigations which use probes as the principal measuring device (Ramfjord et al. 1968, 1973, 1975, Tagge et al. 1975, Nyman et al. 1975, Zamet 1975, Knowles et al. 1976, Burgett \& Knowles 1976, Lang et al. 1976, Morrison et al. 1976). Increased attachment levels following periodontal therapy which are based on probe measurements should not necessarily be equated with connective tissue attachment gains.

From the present study it is concluded that in beagle dogs (1) periodontal probes do not precisely measure connective tissue attachment levels, (2) inflammation has a significant influence on the degree of probe penetration, and (3) histological and clinical sulcus depths differ significantly.

\section{Acknowledgements}

This study was supported in part by USPHS Grant DE02731-09 from the National Institute of Dental Research. The authors wish to thank Dr. James K. Avery and the University of Michigan for use of their laboratory facilities. Appreciation is also extended to Mr. A. A. Tomaro for his technical assistance.

\section{Zusammenfassung}

Mikroskopische Auswertung klinischer Messungen des bindegeweblichen Attachmentniveaus Diese Studie beabsichtigt festzustellen, mit welchem Genauigkeitsgrad Parodontalsonden das Niveau des bindegweblichen Attachments bestimmen können. Die Versuche sind an Beagles-Hunden bei (1) klinisch gesunder Gin- 
giva, (2) experimentell hervorgerufener Gingivitis und (3) Parodontitis vorgenommen worden. Bei gesunder und bei experimentell hervorgerufener Gingivitis wurden die Parodontalsonden mit einem standardisierten Kraftaufwand von 25 Pond in die entsprechenden $\mathrm{Pa}$ rodontien inseriert. Bei Parodontien mit Parodontitis wurden die Sonden mit mildem, jedoch nicht standardisiertem Druck eingeführt. Nach der Applikation wurden die 120 Kunststoffsonden (40 bei jeder Versuchsgruppe) durch Anschmelzen an die Zähne in situ fixiert. Von dem parodontalen Gewebe mit den Sonden in situ wurde nach Blockexzision Serienschnitte hergestellt. Um das Niveau des bindegeweblichen Attachment mit dem Niveau der Penetration der Parodontalsonden vergleichen zu können, wurden die verschiedenen Gewebsabschnitte histometrisch vermessen.

Bei den Präparaten mit gesunden Geweben erreichten die Sonden in keinem Falls die apikale Grenze des Attachmentepithels $(\bar{x}=-0,39$ $\mathrm{mm})$. Bei den Präparaten mit experimenteller Gingivitis lagen die Sondenspitzen näher der epithelialen Attachmentgrenze, doch im Durchschnitt in einer Entfernung von $\bar{x}=-0,10 \mathrm{~mm}$. Bei den Präparaten mit Parodontitis penetirierten die Sonden jedoch in allen Fällen die Region der Zellen des apikalen Attachmentepithels $(\bar{x}=+0,24 \mathrm{~mm})$. Die Abhängigkeit der Sondenpenetration von dem Grad der Entzündung war statistisch sichergestellt. Histologisch gemessene Sulkustiefen standen in keiner Beziehung zu den klinischen Messungen. Als Schlussfolgerungen wurden angegeben: (1) Mit Parodontalsonden werden keine genauen Messungen des Niveaus bindeweblichen Attachments erhalten. (2) Entzündungsvorgänge haben signifikanten Einfluss auf die Sondenpenetration und (3) histologische und klinische Messungen von Taschentiefen sind signifikant unterschiedlich.

\section{Résumé}

Evaluation au microscope du niveau de l'attachement de tissu conjonctif mesuré à l'examen clinique

Le but de la présente étude a été de déterminer avec quelle précision il est possible de mesurer à la sonde parodontale les niveaux de l'attachement de tissu conjonctif chez des chiens briquets présentant 1) une gencive cliniquement saine, 2) une gingivite expérimentale, et 3) une parodontite. Dans les cas de gencives saines et de gingivite expérimentale, les sondes ont été insérées avec une force standardisée de 25 ponds. ( 1 pond $=0,0098 \mathrm{~N}$ ). Dans les cas de parodontites, les sondes ont été insérées avec une force légère, mais non standardisée. Après insertion, 120 sondes parodontales de matière plastique (40 dans chaque groupe) ont été maintenues en place en les fixant sur les dents. Des blocs de tissus parodontaux avec les sondes en place ont ensuite été préparés et des coupes en séries ont été faites. On a ensuite effectué des mesures histométriques de ces coupes, pour comparer le niveau de l'attachement de tissu conjonctif avec le niveau de pénétration de la sonde. Dans aucun des specimens sains, les sondes n'arrivaient au niveau de la limite apicale de l'attache épithéliale ( $\tilde{\mathrm{x}}=$ $-0,39 \mathrm{~mm})$. Dans le groupe de la gingivite expérimentale, la plupart des sondes atteignaient un niveau plus proche de la limite apicale de l'attache épithéliale mais en restaient cependant en moyenne à une distance $\bar{x}=-0,10$ $\mathrm{mm}$. Dans les spécimens des cas de parodontite, les sondes dépassaient toujours les cellules les plus apicales de l'épithélium de jonction $(\overline{\mathrm{x}}=+0,24 \mathrm{~mm})$. Un rapport significatif a été mis en évidence entre le degré de l'inflammation et le niveau de pénétration de la sonde. Aucun rapport n'a été observé entre la profondeur histologique des culs-de-sac et celle qu'on mesurait en clinique. Cette étude permet de conclure que, chez le chien briquet, 1) les sondes parodontales ne donnent pas une mesure précise des niveaux de l'attachement du tissu conjonctif, 2) l'inflammation a une influence significative sur le degré de pénétration de la sonde, et 3) les profondeurs histologiques et cliniques des culs-de-sac différent de façon significative.

\section{References}

Bass, C. C. (1948) The necessary personal oral hygiene for prevention of caries and periodontoclasia. New Orleans Medical and Surgical Journal 101, 52-70.

Black, G. V. (1915) A Work on Special Dental Pathology, 1st ed., p. 17. Chicago: MedicoDental Publishing Co.

Burgett, F. G. \& Knowles, J. W. (1976) Short term results of periodontal surgery relative to methods, types and surfaces of teeth. Journal of Dental Research 55 (Special Issue B), Abstract nr. 983, B307. 
Cohen, B. (1962) A study of the periodontal epithelium. British Dental Journal 112, 5568.

Egelberg, J. (1966) The blood vessels of the dento-gingival junction. Journal of Periodontal Research 1, 163-179.

Everett, F. G. (1971) In Foreword to: Fine structure of the developing epithelial attachment of human teeth. Monographs in Developmental Biology, Vol. 2, Schroeder, H. E. \& Listgarten, M. A. (A. Wolsky, ed.), pp. xixiii. Basel: S. Karger.

Gabathuler, H. \& Hassell, T. (1971) A pressure-sensitive periodontal probe. Helvetica Odontologica Acta 15, 114-117.

Glavind, L. \& Löe, H. (1967) Errors in the clinical assessment of periodontal destruction. Journal of Periodontal Research 2, 180-184.

Gottlieb, B. (1921) Der Epithelansatz am Zahne. Deutsche Monatsschrift für Zahnheilkunde 39, 142-147.

Knowles, J. W., Ramfjord, S. P., Nissle, R. R. \& Burgett, F. G. (1976) Relation of initial pocket depth to periodontal treatment objectives. Journal of Dental Research $\mathbf{5 5}$ (Special Issue B), Abstract no. 988, B309.

Lang, N. P., Morrison, E. C., Löe, H. \& Ramfjord, S. P. (1976) Effects of surgical methods on the level of periodontal attachment and pocket depth in beagle dogs. Journal of Dental Research 55 (Special Issue B), Abstract no. 982, B307.

Lawther, G. C. (1957) Relationships of periodontal instruments to soft tissues of periodontal pockets. M. S. D. Thesis. University of Minnesota, Minneapolis.

Listgarten, M. A. (1972) Normal development, structure, physiology and repair of gingival epithelium. Oral Sciences Reviews 1, 3-67.

Listgarten, M. A., Mao, R. \& Robinson, P. J. (1976) Periodontal probing and the relationship of the probe tip to periodontal tissues. Journal of Periodontology 47, 511-513.

Löe, H. \& Silness, J. (1963) Periodontal disease in pregnancy. I. Prevalence and severity. Acta Odontologica Scandinavica 21, 533551.

Löe, H. \& Holm-Pedersen, P. (1965) Absence and presence of fluid from normal and inflamed gingivae. Periodontics 3, 171-177.

Luna, L. G. (1968) Manual of Histologic Staining Methods of the Armed Forces Institute of Pathology. 3rd ed., New York: The Blakiston Division, McGraw-Hill Book Co.
Morrison, E. C., Lang, N. P. \& Löe, H. (1976) Effects of controlled oral hygiene and repeated scaling on periodontal attachment and pocket depth in beagle dogs. Journal of Dental Research 55 (Special Issue B), Abstract no. 801, B262.

Neiders, M. E. (1972) Contact phenomena of epithelial cells. Oral Sciences Reviews 1, 69101.

Nyman, S., Rosling, B. \& Lindhe, J. (1975) Effect of professional tooth cleaning on healing after periodontal surgery. Journal of Clinical Periodontology 2, 80-86.

Orban, B. J. (1960) Current concepts concerning gingival anatomy. Epithelial attachment (the attached epithelial cuff). Dental Clinics of North America, 705-713.

Orban, B. J., Bhatia, H., Kollar, J. A. \& Wentz, F. M. (1956) The epithelial attachment (the attached epithelial cuff). Journal of Periodontology 27, 167-180.

Ramfjord, S. P., Nissle, R. R., Shick, R. A. \& Copper, H. (1968) Subgingival curettage versus surgical elimination of periodontal pockets. Journal of Periodontology 39, 167-175.

Ramfjord, S. P., Knowles, J. W., Nissle, R. R., Shick, R. A. \& Burgett, F. G. (1973) Longitudinal study of periodontal therapy. Journal of Periodontology 44, 66-77.

Ramfjord, S. P., Knowles, J. W., Nissle, R. R., Burgett, F. G. \& Shick, R. A. (1975) Results following three modalities of periodontal surgery. Journal of Periodontology 46, 522526.

Saglie, R., Johansen, J. R. \& Fløtra, L. (1975) The zone of completely and partially destructed periodontal fibres in pathological pockets. Journal of Clinical Periodontology 2, 198-202.

Schroeder, H. E. \& Listgarten, M. A. (1971) Fine structure of the developing epithelial attachment of human teeth. Monographs in Developmental Biology, Vol. 2, ed. A. Wolsky. Basel: S. Karger.

Silness, J. \& Löe, H. (1964) Periodontal disease in pregnancy. II. Correlation between oral hygiene and periodontal condition. Acta Odontologica Scandinavica 22, 121-135.

Sivertson, J. F. \& Burgett, F. G. (1976) Probing of pockets related to attachment level. Journal of Periodontology 47, 281-286.

Tagge, D. L., O'Leary, T. J. \& El-Kafrawy, A. H. (1975) The clinical and histological response of periodontal pockets to root planing and oral hygiene. Journal of Periodontology 46, 527-533. 
Waerhaug, J. (1952) The gingival pocket. Odontologisk Tidskrift 60, Suppl. 1.

Waerhaug, J. (1960) Current concepts concerning gingival anatomy. The dynamic epithelial cuff. Dental Clinics of North America, 715722.

Weinreb, M. M. (1960) The epithelial attachment. Journal of Periodontology 31, 186196.

Zamet, J. S. (1975) A comparative clinical study of three periodontal surgical techniques. Journal of Clinical Periodontology 2, 87-97.
Zander, H. A. (1956) A method for studying the "epithelial attachment." Journal of Dental Research 35, 308-312.

Address:

Dr. Gary C. Armitage

Division of Periodontology, 681-HSW

School of Dentistry

University of California

San Francisco, California 94143

U.S.A. 
This document is a scanned copy of a printed document. No warranty is given about the accuracy of the copy. Users should refer to the original published version of the material. 